\title{
Antibacterial activity of Turkish honey against selected foodborne pathogens
}

\author{
Güzin İPLİKÇİĞLU-ÇíL ${ }^{1, a}$, Özlem KÜPLÜLÜ ${ }^{1, b}$, Görkem CENGíZ1,c,®, Seda Dicle KORKMAZ ${ }^{2, d}$, \\ Buse ARSLAN ${ }^{1, e}$, İsmayil Safa GÜRCAN ${ }^{3, f}$
}

\begin{abstract}
${ }^{1}$ Ankara University, Faculty of Veterinary Medicine, Department of Food Hygiene and Technology, Ankara; ${ }^{2}$ Giresun University, Espiye Vocational School, Giresun; ${ }^{3}$ Ankara University, Faculty of Veterinary Medicine, Department of Biostatistics, Ankara, Turkey.

${ }^{\mathrm{a} O R C I D:}$ 0000-0001-6897-8222; b ORCID: 0000-0002-1559-2390; ' $\mathrm{ORCID:}$ 0000-0001-9853-565X; ${ }^{\mathrm{d} O R C I D: 0000-0002-4272-300 X ; ~}{ }^{\mathrm{e} O R C I D: 0000-0001-6479-1698 ; ~}{ }^{\mathrm{f} O R C I D: 0000-0002-0738-1518 .}$
\end{abstract}

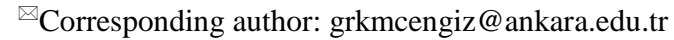

Received date: 14.01.2020 - Accepted date: 17.03.2020

\begin{abstract}
Honey is an important animal product that is consumed by people of all ages and has become an important antimicrobial agent because it has both antibacterial properties and does not cause microbial resistance. Although, Turkey is among the most important honey producers of the world, there are not enough studies about the antibacterial activity of Turkish honey. According to their geographical area, honey exhibit considerable and variable antimicrobial activity. In this study, we investigated the in vitro antibacterial effect of honey obtained from Turkey, against Escherichia coli, Listeria monocytogenes, Salmonella Typhimurium and Staphylococcus aureus by using agar dilution, agar well diffusion and disc diffusion methods and compared the efficacy of these methods. Results showed the antibacterial effects of Turkish honey, collected from different regions against selected pathogens. Different concentrations of all honey samples displayed an antibacterial activity. Each microorganism exhibited different sensitivity to the honey tested. In addition, a significant difference was detected between the three methods for each microorganism and well diffusion method was found to be the most sensitive method.
\end{abstract}

Keywords: Agar dilution, agar-well diffusion, antimicrobial effect, disc diffusion, honey.

\section{Türk balının seçili gıda patojenlerine karşı antibakteriyel aktivitesi}

Özet: Bal her yaştan insanın sıklıkla tükettiği önemli bir hayvansal ürün olmasının yanı sıra hem antibakteriyel özelliklere sahip olması hem de mikrobiyal dirence neden olmaması sebebiyle önem arz eden antimikrobiyal bir ajan haline gelmiştir. Türkiye, dünyanın en önemli bal üreticileri arasında yer almasına rağmen, Türk ballarının antibakteriyel aktivitesi hakkında yeterli çalışma bulunmamaktadır. Ballar, coğrafi bölgelerine göre değişken antimikrobiyal aktivite sergilemektedir. Bu kapsamda bu çalışmada Türkiye'nin farklı bölgelerinden toplanan balların Escherichia coli, Listeria monocytogenes, Salmonella Typhimurium ve Staphylococcus aureus'a karşı in vitro antibakteriyel etkisinin, agar dilüsyon, agar-well difüzyon ve disk difüzyon yöntemleri kullanarak araştırılması ve bu yöntemlerin etkinliğinin karşılaştırılması amaçlanmıştır. Sonuçlar farklı bölgelerinden toplanan Türk ballarının, seçili gıda patojenlerine karşı antibakteriyel etkilerinin olduğunu göstermiştir. Her mikroorganizmanın test edilen ballara karşı farklı duyarlılığa sahip olduğu belirlenmiştir. Ayrıca seçilen bu üç yöntem arasında anlamlı bir fark olduğu, agar-well difüzyon yönteminin ise en hassas yöntem olduğu tespit edilmiştir.

Anahtar sözcükler: Agar dilüsyon, agar-well difüzyon, antimikrobiyal etki, bal, disk difüzyon

\section{Introduction}

Honey has been used since ancient times not only in food and beverages but also for the treatment of diseases (11). In recent years, apitherapy, an alternative medicine branch has developed based on the use of honey and bee products against many diseases. The major use of honey in treatment is in wounds, burns and bacterial infections $(8,22)$. In addition, the use of antimicrobial compounds naturally found in foods are of high interest, because of antibiotic resistant bacteria frequencies are increasing worldwide. Honey is a promising antibacterial agent, because microbial resistance to honey has never been reported (14).

Various factors have contribution to the antimicrobial activity of honey. The antibacterial properties of honey have been associated primarily to hydrogen peroxide, which is produced from the enzyme glucose oxidase. However, honey has a quite complex 
structure varying to its botanical origin, different components including, methylglyoxal, bee defensing-1, lysozyme, and florally derived phenolics other yet undetermined compounds have been also attributed to this important property of honey. These components have been grouped together and the antibacterial activity derived from them called non-peroxide dependent activity in the literature. In addition to these factors, high sugar concentration and its effect on osmolarity are also associated with the antibacterial effect of honey $(5,6)$.

Turkey is one of the biggest honey producers in the world. Twenty percent of the world's 25 bee sub-species can be found in Turkey and $70 \%$ of plants in Turkey are floristic. Honey is produced in almost every region of Turkey, which provides diversity to the honey produced in Turkey. Mixed flower honey, thyme honey, chestnut honey, rhododendron honey, mountain meadow honey, and citrus honey are some of the most famous honey types in Turkey. In addition, Turkey has the largest share of the world's pine honey production $(2,13)$.

Honey are not equal in their effectiveness. According to their geographical area, honey exhibit considerable and variable antimicrobial activity. For example, Manuka honey, which originates from a tree, Leptospermum scoparium produced in New Zealand and Australia, best known and sold as a therapeutic agent worldwide. Tualang honey has been documented also like the same antibacterial activity. The compositional differences of honey can influence its medicinal value $(7,9)$.

To date, there are many publications reporting the antibacterial effects of honey against gram negative and gram-positive bacteria, especially to the ones, which are related to wounds. Controlling the growth or elimination of the foodborne pathogens by using natural antimicrobials is also great interest. In this study, we investigated the in vitro antibacterial effect of honey obtained from different regions of Turkey, against some important foodborne pathogens, Escherichia coli, Listeria monocytogenes, Salmonella Typhimurium and Staphylococcus aureus. For this purpose, three common methods, which are, agar dilution, agar well diffusion and disc diffusion, selected and the efficacy of these methods compared to the detection of antibacterial activity.

\section{Materials and Methods}

Honey samples: The study was carried out with 50 freshly harvested, unpasteurized, untreated and natural honey samples, obtained from the local beekeepers in different regions of Turkey. Each sample was collected in sterile containers and kept at room temperature, in the dark, until tested.

A serial dilution of honey from $50 \%$ to $0.022 \%(\mathrm{w} / \mathrm{v})$ was prepared aseptically in order to use in all methods. From the $50 \%$ honey solution, 12 serials $1: 1$ dilution were made by using sterile distilled water, in a final concentration of $50 \%, 25 \%, 12.5 \%, 6 \%, 3 \%, 1.5 \%$, $0.75 \%, 0.37 \%, 0.18 \%, 0.09 \%, 0.045 \%$ and $0.022 \%$. All of the honey samples tested were at room temperature.

Artificial honey was prepared according to Zainol et al. (30), by dissolving $40.5 \%$ fructose (Sigma, US), $7.5 \%$ maltose (Difco, US), 33.5\% glucose (Difco, US), and $1.5 \%$ sucrose (Difco, US) in a final volume of $100 \mathrm{ml}$ sterile distilled water. The same serial dilutions of artificial from $50 \%$ to 0.022 were also prepared.

Bacterial strains: The antibacterial properties of honey were tested against four common foodborne pathogens. Escherichia coli ATCC 12900, Listeria monocytogenes ATCC 7644, Salmonella Typhimurium ATCC 14028, and Staphylococcus aureus ATCC 25923 was used as reference strains. Each of the strains was inoculated into Brain Heart Infusion Broth (Oxoid, UK), and incubated overnight at $37{ }^{\circ} \mathrm{C}$ and adjusted to 0.5 optical density at $450 \mathrm{~nm}$ in sterile buffered peptone water (Oxoid, UK).

Disc diffusion method: A sterile cotton swab was dipped into the cultures of each test pathogen prepared as described above and inoculated by swabbing into the surface of Nutrient agar (Oxoid, UK) plates. Plates were allowed to dry for $15 \mathrm{~min}$ at room temperature before discs were applied. Sterile absorbent blank discs $(6 \mathrm{~mm}$ diameter, Oxoid, UK) were placed into honey concentrations for $10 \mathrm{~min}$ before being applied. Thereafter, all disks were placed on the plates and pressed gently to ensure complete contact with agar. Fifteen mm distance was maintained from the edges of the plates and between the disks, to prevent overlapping of inhibition zones. Sterile blank disk and methylene blue dye-soaked disk were used as a control. Plates were incubated at $37^{\circ} \mathrm{C}$ for $24 \mathrm{hr}$. After the incubation period, they were examined and the diameter zones of inhibition measured by using an electronic caliper (Asimeto, Germany) (23).

Well diffusion method: One $\mathrm{ml}$ from each test pathogen mixed with $20 \mathrm{ml}$ freshly prepared nutrient agar and immediately poured into culture plates. Wells $8 \mathrm{~mm}$ diameter were bored into the surface of the agar. 180 microliters of each dilution of honey were placed into each well. Methylene blue (Merck, Germany) was used as a control. Plates were allowed to diffuse during the incubation at $37^{\circ} \mathrm{C}$ for $24 \mathrm{hr}$. Following the incubation zones of inhibition were measured (23).

Agar dilution method: Agar dilution method was carried out according to Lusby et al. (18) with some modifications. A nutrient agar/honey mix was prepared for each honey at concentrations from $50 \%$ to $0.022 \%$. From each bacterial culture, $1 \mathrm{ml}$ was put into the plates and the mixtures were poured onto them. Plates were incubated at $37^{\circ} \mathrm{C}$ for $24 \mathrm{hr}$. After the incubation period, they were examined.

Statistical analysis: The Friedman test was used to determine the difference between the three different 
methods used to detect the same bacterial strain and the one-sample Wilcoxon signed rank test was used to compare the results of honey used and the artificial honey as a control. All data presented median values. A probability value $\mathrm{P}<0.05$ was taken as significant. Statistical analyzes were performed using SPSS Ver. 22 statistical package program.

\section{Results}

Inhibition of bacterial growth by honey and the frequency distributions of the dilutions that the antibacterial effect has been determined according to each microorganism are shown in the Figure 1- 4.

The Friedman test is used to test whether there is a significant difference between distributions by comparing

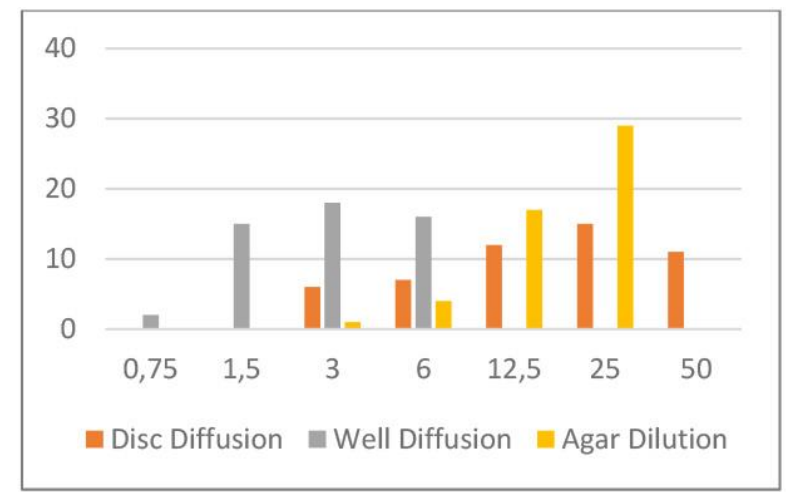

Figure 1. Frequency distribution for $S$. Typhimurium.

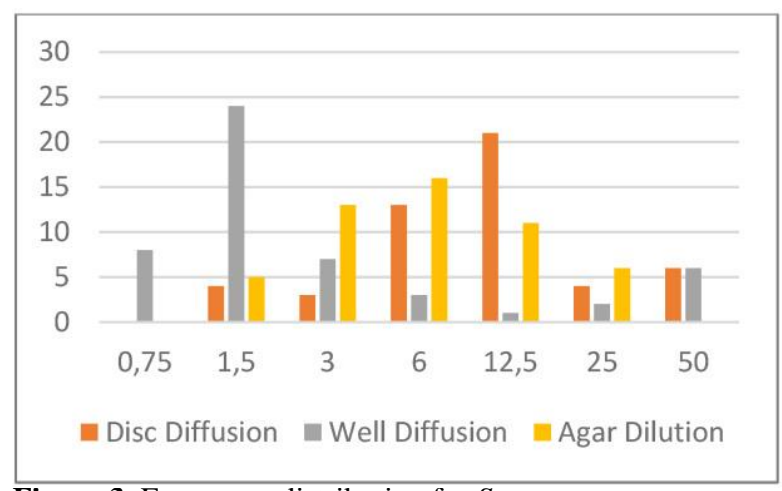

Figure 3. Frequency distribution for $S$. aureus. distributions of two or more related groups. In other words, it is examined whether there is a difference between repeated measurements of a sample. The Friedman test is an alternative to one-way analysis of variance for associated or repeated measures if the conditions for the use of parametric tests are not met. In Table 1, it can be seen the results of the Friedman test. As a result, there is a significant difference between the three methods for each microorganism and well diffusion method was found to be the most sensitive method for the detection of the antibacterial effect.

Table 2 indicates the results of the one-sample Wilcoxon signed rank test. When compared with artificial honey, our honey samples in different methods showed a significant difference.

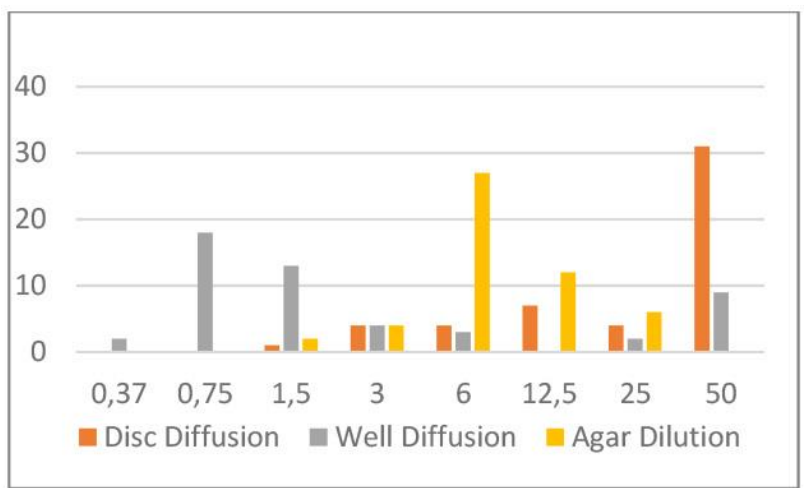

Figure 2. Frequency distribution for L. monocytogenes.

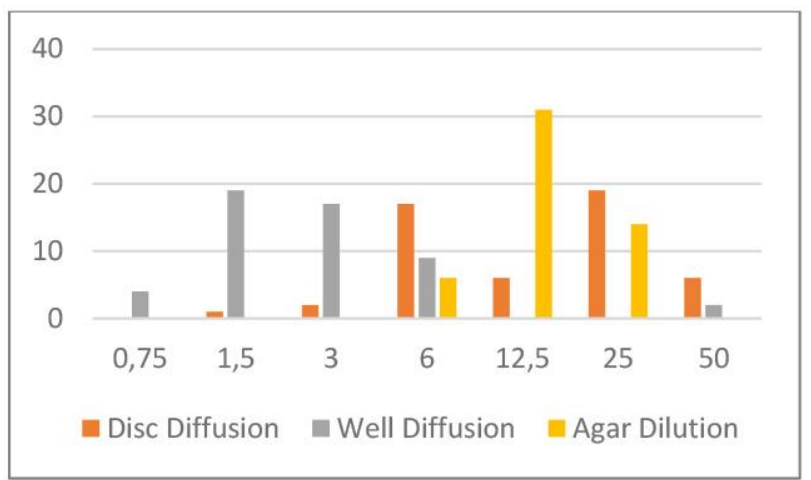

Figure 4. Frequency distribution for E. coli.

Table 1. Results of the comparison of the three methods used for each microorganism.

\begin{tabular}{|c|c|c|c|c|c|c|}
\hline & & & Disc diffusion & Well diffusion & Agar dilution & $\mathbf{P}$ \\
\hline \multirow{3}{*}{$S$. Typhimurium } & $\mathrm{N}$ & Valid & 51 & 51 & 51 & \\
\hline & Mean & & 22.2549 & 3.4118 & 18.9118 & \\
\hline & Median & & 25.0000 & 3.0000 & 25.0000 & $\mathrm{P}<0.001$ \\
\hline \multirow{3}{*}{ L. monocytogenes } & $\mathrm{N}$ & Valid & 51 & 51 & 51 & \\
\hline & Mean & & 34.8039 & 11.0537 & 9.3529 & \\
\hline & Median & & 50.0000 & 1.5000 & 6.0000 & $\mathrm{P}<0.001$ \\
\hline \multirow{3}{*}{ S. aureus } & $\mathrm{N}$ & Valid & 51 & 51 & 51 & \\
\hline & Mean & & 14.8137 & 8.6961 & 8.4314 & \\
\hline & Median & & 12.5000 & 1.5000 & 6.0000 & $P<0.001$ \\
\hline \multirow{3}{*}{ E. coli } & $\mathrm{N}$ & Valid & 51 & 51 & 51 & \\
\hline & Mean & & 18.8137 & 4.6373 & 15.1667 & \\
\hline & Median & & 12.5000 & 3.0000 & 12.5000 & $\mathrm{P}<0.001$ \\
\hline
\end{tabular}


Table 2. Comparison of the artificial honey and honey sample results according to the microorganisms and methods.

\begin{tabular}{|c|c|c|c|c|c|}
\hline & & & Disc Diffusion & Well Diffusion & Agar Dilution \\
\hline \multirow{4}{*}{$S$. Typhimurium } & $\mathrm{N}$ & Valid & 50 & 50 & 50 \\
\hline & Artificial honey & & 50.0000 & 6.0000 & 50.0000 \\
\hline & Median & & 25.0000 & 3.0000 & 25.0000 \\
\hline & $\mathrm{P}$ & & $\mathrm{P}<0.01$ & $\mathrm{P}<0.05$ & $\mathrm{P}<0.01$ \\
\hline \multirow{4}{*}{ L. monocytogenes } & $\mathrm{N}$ & Valid & 50 & 50 & 50 \\
\hline & Artificial honey & & 50.0000 & 6.0000 & 50.0000 \\
\hline & Median & & 50.0000 & 1.5000 & 6.0000 \\
\hline & $\mathrm{P}$ & & $\mathrm{P}>0.05$ & $\mathrm{P}<0.05$ & $\mathrm{P}<0.001$ \\
\hline \multirow{4}{*}{ S. aureus } & $\mathrm{N}$ & Valid & 50 & 50 & 50 \\
\hline & Artificial honey & & 12.5000 & 50.0000 & 50.0000 \\
\hline & Median & & 12.5000 & 1.5000 & 6.0000 \\
\hline & $\mathrm{P}$ & & $\mathrm{P}>0.05$ & $\mathrm{P}<0.001$ & $\mathrm{P}<0.001$ \\
\hline \multirow{4}{*}{ E. coli } & $\mathrm{N}$ & Valid & 50 & 50 & 50 \\
\hline & Artificial honey & & 50.0000 & 3.0000 & 50.0000 \\
\hline & Median & & 12.5000 & 3.0000 & 12.5000 \\
\hline & $\mathrm{P}$ & & $\mathrm{P}<0.01$ & $\mathrm{P}>0.05$ & $\mathrm{P}<0.01$ \\
\hline
\end{tabular}

\section{Discussion and Conclusion}

Public interest has been growing to the alternative substances, due to the side effects and the emergence of antibiotic resistant pathogens and honey, is the most noticeable one among them. However, its mechanism still not being well understood and the efficacy on the pathogens is not standardized (16). In this study, we investigated the in vitro antibacterial effect of honey obtained from different regions of Turkey, against some important foodborne pathogens, and the efficacy of the selected assays also compared for the detection of antibacterial activity.

Results showed the antibacterial effects of Turkish honey, collected from different regions against four important foodborne pathogens. Different concentrations of all honey samples displayed an antibacterial activity. Each microorganism exhibited different sensitivity to the honey tested.

Properties associated with the antibacterial activity of honey significantly affected by geographic location and botanical origin. Honey is a natural product and created from a variety of plants so the nutritional and medicinal profile of each honey varies (1). Studies exhibit the considerable and variable antibacterial activity of honey from different geographical areas against Gram-negative and Gram-positive bacteria. Ramos et al. (24) assess the antibacterial action of 24 honey samples harvested from the three regions of Argentina, against microorganisms isolated from contaminated food by an agar diffusion test. Most 1:2 (w/v) honey dilutions had an antimicrobial effect for E. coli, Salmonella spp., S. aureus, Pseudomons aeruginosa and Bacillus cereus strains tested. Some honey lost their ability to inhibit bacterial growth at 1:4 (w/v) dilutions. Deng et al. (12) compared the buckwheat honey antibacterial activity with the Manuka honey against $S$. aureus. The agar well diffusion test and from $100 \%$ to $5 \%$ $(w / v)$ honey dilutions were used to screen the antibacterial activity of honey. At the concentrations of $30-100 \%$, the inhibition zones of buckwheat honey were found to be larger than those of Manuka honey. Similarly, in the study of Anthimidou and Mossialis (3), the antibacterial effect of Greek and Cypriot honeys' compared with the Manuka honey. They reported that according to the results of agarwell diffusion assay, all tested honey samples had antibacterial effect against $S$. aureus. In addition, from the 31 samples, 14 demonstrated significantly larger zones than the Manuka honey. In another study, the antibacterial activity of stingless bee honey from Borneo (Sarawak) was evaluated by the disc diffusion method against selected Gram-negative and Gram-positive bacteria. All honey showed antibacterial activity against tested microorganisms (28). Matzen et al. (20) surveyed 11 honey of various Danish floral sources for their antibacterial activity by using the agar-well diffusion method. All honey tested, exhibited antibacterial activity, against S. aureus, S. epidermidis, $P$. aeruginosa and E. coli.

Although, Turkey is among the important honey producers of the world, there are not enough studies about the antibacterial activity of Turkish honey. Sagdic et al. (25), evaluate the antibacterial activity of 35 multifloral Turkish honey, by the agar diffusion method, using 12 bacteria and 2 yeasts. Results showed that the concentration of honey at 5, 10, and $25 \%$ had no inhibitory effect on the 14 microorganisms tested but at $75 \%$ concentration the highest antimicrobial activity against $E$. coli 0157:H7, S. Typhimurium, S. aureus, $L$. monocytogenes, and $P$. mirabilis was observed. Mercan et al. (21) detected the antimicrobial activity of five honey samples from Turkey, concentrations at 20, 50 and $70 \%$, by agar well diffusion method against 8 selected pathogens. They reported that inhibition zones were observed to increase with the honey concentration.

What is the optimal amount of honey needed to observe the antibacterial activity, is an important question to be asked? Especially for the foodborne pathogens, because in wounds whole honey is topically applied. 
When the honey ingested, it is diluted in the body. Studies showed that the inhibitory effect of honey may range from concentrations $<3 \%$ to $50 \%$ and higher $(1,7)$. Therefore, in the studies different concentrations of the honey samples are preferred by the researchers. In this study, a serial dilution was used for each honey sample from $50 \%$ to $0.022 \%$ for all microorganisms and all the three methods. A diversity was observed in the concentration results. For example, the mean dilution for the $L$. monocytogenes is $1.5 \%$ for the well diffusion method, but for disc diffusion the mean value determined as $50 \%$. For $S$. Typhimurium, disc diffusion and agar dilution methods were found in the same mean values like $25 \%$, while in well diffusion assay the mean value was recorded as $3 \%$. This variety is thought to be related to the method used and the sensitivity of the microorganisms. In the studies, the antibacterial activity of honey is also reported to be dependent on the nature of the pathogens selected and the concentration of honey tested (19).

In the study, three different methods were chosen to detect the antibacterial activity of the samples. These three assays are the most common methods used by the researchers. Results allowed the comparison of the methods. The comparison of the three methods using the same samples in equal conditions is another important aspect of this study. A significant difference was detected between the methods for each microorganism. Among the three methods, well diffusion assay was found to be the most sensitive one for the detection of the antibacterial effect (Table 1). Lusby et al. (18) used the agar dilution method to assess the antibacterial activity and according to them the honey is incorporated directly into the growth media in agar dilution method; so they thought that the bacteria are brought into direct contact with all honey components directly on application to the agar rather than waiting the diffusion of constituents through the agar. Also, they suggested that the agar diffusion method mimics the situation within the wound treated with honey in the best way. The disc diffusion assay is regarded as the method of choice for the inhibition tests because this method is the most common one used to test antibiotics (23). According to Casey et al. (10) although the disc diffusion and well diffusion methods are widely used in previous studies, in these methods instead of seeding the agar, the cultures were overlaid onto the agar surface, because the microorganisms are in an early growth phase, it can be resulted as the easier detection of inhibition. Kwakman and Zaat (15) pointed out the limitations of the agar diffusion method. They indicated that, the rate of diffusion of the antibacterial component through the agar matrix also effects the size of the zone, honey with the relatively high molecular weight which have limited migration in the agar may be measured incorrectly having low activity. In accordance with, Tan et al. (27) reported that, the MIC values determined by the broth dilution method were lower than those obtained with the agar well diffusion assay, as the diffusion rates of active compounds in agar may be slower than in broth. Zainol et al. (30) prefer to use well diffusion instead of disk diffusion in their study and they explained it as; the use of disk may lead to the exclusion of large molecules in the honey, which are not properly absorbed by the disc and could contribute inaccurate results. The selection of the method is depending on the requested data, qualitative or quantitative, at the end of the study. In addition, time, sample and cost implications are also associated with the choice of method.

Some of the pathogens can be inhibited by low levels of osmolarity. Antibacterial activity of honey may have attributed to the sugar content rather than the other constitutes. Therefore, to include an artificial honey or a sugar solution as a reference to the studies is essential to distinguish the antibacterial efficacy than the osmolarity (17). In this study, an artificial honey was used to reveal this condition. According to the results, in most of the methods used in different microorganisms, a significant difference was detected between the tested samples and the artificial honey (Table 2). Wilkinson and Cavanagh (29) used an artificial honey in their study and compare the results with the honey samples tested. At $10 \%$ and 5\% artificial honey was able to inhibit the growth of $P$. aeruginosa but had no measurable effect on the growth of $E$. coli, while all honey tested had an inhibitory effect on the growth of $E$. coli and $P$. aeruginosa. Similarly, Shamala et al. (26) used $80 \%$ glucose, fructose and sucrose solutions for comparison in their study. They reported the mean inhibition zones obtained against $E$. coli by well assay were 35,27 and $40 \mathrm{~mm}$ for glucose, fructose and honey respectively. In addition, no visible zone was reported around the sucrose well. In Zainol et al. (30) study, artificial honey was used to exclude the osmotic effect of honey against the selected pathogens. Results showed that all bacteria were inhibited at $50 \%(\mathrm{w} / \mathrm{v})$ concentration while the results of honey tested were lower and no bactericidal effect was recorded when the artificial honey was used. In contrast with these results, Basson and Grobler (4) reported in their study that, at the same concentrations, honey and the control carbohydrate solution had the similar activity towards all the microorganisms tested. Matzen et al. (20), determined that the pure sugar samples ( $75 \%$ and $15 \%$ sucrose) showed no inhibition on the five selected pathogens compared with the Danish honey samples tested.

The antibacterial effect of Turkish honey against selected pathogens seems promising. This data also points out other than the commercially available antibacterial honey such as; Manuka or Tualang, Turkish honey can have potent antibacterial activity against pathogens. However, this activity should be demonstrated by studies and the chemical and antibacterial structures of Turkish honey should be researched and standardized. There is a large disparity between the methods used to evaluate the 
antibacterial activity of honey. Limits of detection, sensitivity, cost implications, repeatability are some of the reasons for this diversity. By the increase of comparative studies like ours, it will be easier to identify the most effective method for the detection of the antibacterial activity. In addition, results of the in vitro studies like us, should be supported by in vivo studies. Also, for further researches and to support these results, wild type of the pathogens can be tested, because of the standard strains sensitivity to external factors.

\section{Financial Support}

This research received no grant from any funding agency/sector.

\section{Ethical Statement}

This study does not present any ethical concerns.

\section{Conflict of Interest}

The authors declared that there is no conflict of interest.

\section{References}

1. Al-Waili NS, Salom K, Butler G, et al (2011): Honey and microbial infections: a review supporting the use of honey for microbial control. J Med Food 14, 1079-1096.

2. Anonymus (2015): The Turkish Beekeeping and Honey Sector. USDA Foreign Agricultural Service. Global Agricultural Information Network. GAIN report Avaliable at https://www.fas.usda.gov/data/turkey-turkishbeekeeping-and-honey-sector. (Accessed June 20, 2019)

3. Anthimidou E, Mossialos D (2013): Antibacterial activity of Greek and Cypriot honeys against Staphylococcus aureus and Pseudomonas aeruginosa in comparison to manuka honey. J Med Food 16, 42-47.

4. Basson NJ, Grobler SR (2008): Antimicrobial activity of two South African honeys produced from indigenous Leucospermum cordifolium and Erica species on selected microorganisms. BMC Complem Altern M 8, 41 .

5. Bizerra FC, Da Silva Junior PI, Hayashi MA (2012): Exploring the antibacterial properties of honey and its potential. Front Microbiol 3, 398.

6. Blair SE, Carter DA (2005): The potential for honey in the management of wounds and infection. Healthcare Inf 10, 24-31.

7. Bogdanov S (2012): Honey as nutrient and functional food. Proteins 1100, 1400-2700.

8. Bogdanov S, Jurendic T, Sieber R, et al (2008): Honey for nutrition and health: a review. J Am Coll Nutr 27, 677-689.

9. Burns DT, Dillon A, Warren J, et al (2018): A critical review of the factors available for the identification and determination of Mānuka honey. Food Anal Method 11, 1561-1567.

10. Casey JT, O'Cleirigh C, Walsh PK, et al (2004): Development of a robust microtiter plate-based assay method for assessment of bioactivity. J Microbiol Meth 58, 327-334.

11. Chen C, Campbell L, Blair SE, et al (2012): The effect of standard heat and filtration processing procedures on antimicrobial activity and hydrogen peroxide levels in honey. Front Microbiol 3, 265.
12. Deng J, Liu R, Lu Q, et al (2018): Biochemical properties, antibacterial and cellular antioxidant activities of buckwheat honey in comparison to manuka honey. Food Chem 252, 243-249.

13. Korkmaz SD, Kuplulu O, Cil GI, et al (2017): Detection of sulfonamide and tetracycline antibiotic residues in Turkish pine honey. Int J Food Prop 20, 50-55.

14. Kwakman PHS, Van den Akker JPC, Güçlü A, et al (2008): Medical-grade honey kills antibiotic-resistant bacteria in vitro and eradicates skin colonization. Clin Infect Dis 46, 1677-1682.

15. Kwakman PH, Zaat SA (2012): Antibacterial components of honey. IUBMB Life 64, 48-55.

16. Kwakman PH, te Velde AA, de Boer L, et al (2010): How honey kills bacteria. FASEB J 24, 2576-2582.

17. Lin SM, Molan PC, Cursons RT (2011): The controlled in vitro susceptibility of gastrointestinal pathogens to the antibacterial effect of manuka honey. Eur J Clin Microbiol 30, 569-574.

18. Lusby PE, Coombes AL, Wilkinson JM (2005): Bactericidal activity of different honeys against pathogenic bacteria. Arch Med Res 36, 464-467.

19. Mandal MD, Mandal S (2011): Honey: its medicinal property and antibacterial activity. Asian Pac J Trop Med 1,154 .

20. Matzen RD, Zinck Leth-Espensen J, Jansson T, et al (2018): The antibacterial effect in vitro of honey derived from various Danish flora. Dermatol Res Pract 2018, 1-10.

21. Mercan N, Guvensen A, Celik A, et al (2007): Antimicrobial activity and pollen composition of honey samples collected from different provinces in Turkey. Nat Prod Res 21, 187-195.

22. Molan P (2001): Why honey is effective as a medicine: 2 . The scientific explanation of its effects. Bee World. 82, 22-40.

23. Patton T, Barrett J, Brennan J, et al (2006): Use of a spectrophotometric bioassay for determination of microbial sensitivity to manuka honey. J Microbiol Meth 64, 84-95.

24. Ramos OY, Salomón V, Libonatti C, et al (2018): Effect of botanical and physicochemical composition of Argentinean honeys on the inhibitory action against food pathogens. LWT Food Sci Technol 87, 457-463.

25. Sagdic O, Silici S, Ekici L (2013): Evaluation of the phenolic content, antiradical, antioxidant, and antimicrobial activity of different floral sources of honey. Int J Food Prop 16, 658-666.

26. Shamala TR, Jyothi YPS, Saibaba P (2002): Antibacterial effect of honey on the in vitro and in vivo growth of Escherichia coli. World J Microb Biot 18, 863-865.

27. Tan HT, Rahman RA, Gan SH, et al (2009): The antibacterial properties of Malaysian tualang honey against wound and enteric microorganisms in comparison to manuka honey. BMC Complem Altern M 9, 34.

28. Tuksitha L, Chen YLS, Chen YL, et al (2018): Antioxidant and antibacterial capacity of stingless bee honey from Borneo (Sarawak). J Asia-Pac Entomol 21, 563570.

29. Wilkinson JM, Cavanagh HM (2005): Antibacterial activity of 13 honeys against Escherichia coli and Pseudomonas aeruginosa. J Med Food 8, 100-103.

30. Zainol MI, Yusoff KM, Yusof MYM (2013): Antibacterial activity of selected Malaysian honey. BMC Complem Altern M 13, 129. 